\title{
MAXIMIZING STUDENTS ENGLISH ABILITY TROUGH FACEBOOK
}

\author{
Siti Mafulah (Corresponding Author) \\ Faculty of Letters of University of Kanjuruhan Malang \\ Jl. S. Supriyadi 48 Malang, Indonesia \\ Phone: (+62) 8175003101 E-mail:ulfasengkaling@ gmail.com
}

\begin{abstract}
The development of social media recently in this era is really attractive to be discussed. Almost all students use their mobile phone to access it. So that why we as teacher cannot use this brilliant tool in learning English.Qodriani (2013) said that Facebook is not just a great way for people to find old friend or know about what happening recently but it is also an incredible learning media that can support teaching and learning activity.Attractive media makes learning enjoyable.The design used in this research was descriptive design with 12 students as participants. This research focuses on the English learning through Facebook. How Facebook used in English language class, how students' perspective of using Facebook in learning English and how Facebook maximize their English will be described in this paper. This activity offers students in learning English and makes enjoyable learning. Moreover students can write and share what they have done or something happened to them without any worrying of making mistake.
\end{abstract}

Keywords: Maximizing, English ability, Facebook

\section{INTRODUCTION}

The development of social media recently in this era is really attractive to be discussed. The function of social media is not only for sharing information but also for learning media. Let's say Facebook, In 2016 the active users of Facebook in Indonesia are 88 million and $94 \%$ users accessing Facebook from their mobile phone. It means that almost students use their mobile phone to access it. So that why we as teacher cannot use this brilliant tool in teaching learning process.

with Facebook, limited exposure to the target language can be overcome (Hanafi et al, 2015) Teacher may give students task in joining news feeds such as CNN students news, adding comments or watching video posted on Facebook and making summary of the video. 
Qodriani (2013) said that Facebook is is not just a great way for people to find old friend or know about what happening recently but it is also an incredible learning media that can support teaching and learning activity. Facebook can be a tool of communication in class group, sharing project and inform some recent references and link. Rokhayani (2012) added the function of Facebook is that can help students increasing passion in learning activity. Teacher and students can have additional time and place to recover limited time provided in class. Students can share their difficulties in the classroom without any worry of being mistake. Facebook help students to find any sources and any English exposure. Furthermore they are familiar with this kind of social media. They often use it to write everything they want, they share everything they want and they follow some page that they really interested in.

Some Previous studies showed that using Facebook is effective. Such as Wang and Chen (2013), they investigated the effects of Facebook tutoring on learning English as a second language. They used 60 elementary students as respondents. The result of this study indicated that the students generally exhibited a positive attitude toward this new type of learning experience. The learning achievement was also significantly higher than he traditional classroom group.

Second study come from Qodriani (2013)she has analyzed about the use of Facebook group Facility in Poetry. The findings showed that the use of Facebook group help recovering the limited time provided in her class. It also solved the problem of teachers that usually lack of time allocation to provide many things for her students through teaching and learning process.

Considering the success of the previous study, In this paper the researcher wants to depict:

1. How Facebook used in English language class

2. Students' perspective of using Facebook in learning English

3. How Facebook maximize their English skills

\section{REVIEW OF RELATED LITERATURE}

Facebook is a social networking service whereby users can create a personal profile, add other users as friends, and exchange messages. This includes automatic notifications when they update their personal profile. Facebook users can also join common-interest user groups that they find useful. Besides updating status and comments, users can chat with friend online and the users will receive automatic notification every time the post being posted.

Facebook builds your English reading skills. Students can read an assortment of messages from those who write. This diversity of messages means you can learn new words from people all over the world, depending on your list of friends.Facebook can help students increase their own language learning in a fun and 
motivating way. It also can help keep topics group together in one place, which is easier for students to read and to control over their length of their posts. Facebook is not only for social communication but also can share photo, attach links, send private message and chat online. There are many terms found in Facebook, namely: news feed, friend online, what's on your mind, share, like, tag this photo and others. In 2016 the active users of Facebook in Indonesia are 88 million and 94\% users accessing Facebook from their mobile phone. It means that all of the students use their mobile phone to access it.

Based on Mazman and Usluel (2010) there are three types of educational functions. They are communication, collaboration and resource sharing. First function is communication. Communication consists of activities such as enabling communication among students and their instructors, facilitating class discussions, delivery of homework and assignments. Second function is informing about the resources and link related to courses. It consists of activities such as people's joining to academic group related to their schools, departments or classes and carrying on group works by sharing homework, project and ideas. And the last function is collaboration. It consists of activities such as exchanging multimedia resources, videos, audio material, animated video, resources and documents.

There are some advantages using Facebook in learning language. Ajjan \& Hartshorne (2008) in Wang and Chen (2013) they recognized that active users could improve their communication and writing skills through virtual social interaction with Facebook.

Qodriani (2013) sated that there are some benefits of using Facebook in Teaching and learning such as : teacher and students can have additional time and place to recover limited time provided in class teaching and learning activity, Facebook is used by students so there is no difficulties to apply it. Facebook group can be set by the group creator as a private community discussion for only certain group of people, so the discussion being in this facility will be safe from somebody who does not belong to the group. Facebook can be used for sharing information, chit-chatting and also can be filled by PDF, JPEG, Doc file, so that the discussion established in the group can be creatively created. And the last is students can directly ask their lecturer or teacher if they have difficulties in understanding certain material or even something unclear instruction .

In line with Qodriani, Hanafi et all (2013) also stated that the benefit of using Facebook is students can access to unlimited resources available online such as news, videos and websites with more natural language and expressions used by native speakers. They also added that by using Facebook students can expose the native speaker expression and the culture, how the native say something; how they use kinds of expression; how native speakers initiate a conversation; how they avoid personal question and so on. And perhaps all kind of this experience cannot be found on the classroom interaction. 
Students learn topic such as interviewing each other, introducing oneself, making conversation of the topic that have been learned and others, in most cases, artificially in nature. While communication that takes place in Facebook is more authentic and contextual for real life purposes in the process of negotiating the meaning. In this case, Facebook can be alternative tool to learn English well.

Some example of how to use Facebook in the EFL Classroom proposed by Hanafi et al (2013) is creating Facebook group. With the group, teacher can see who actively participates in the group, students can submit their assignment online and students can add relevant link. The activity can be posting cartoons or photos and have students comment. Debates or discussion. In this case teacher can post a controversial topic, divides the students into two groups. One group as pro and another group as contrast side. Each group has to give their argument and also the reason why they like it or not. Third is sharing personal experience or story. In this case teacher can ask the students to share their experience and their story on Facebook and the class can vote as to whose experience is the most interesting, whose story is the scariest, why they choose it and so on. Fourth activity is posting relevant links to the group. In this case teacher can ask the students to post relevant links to the group. These links should be related to the topic that they are currently learn in the class. The more links posted the more information can be grasp from the links. From this activity students can access more resources. The last activity they proposes is posting assignment/project. Students can post their assignment/project through inbox or the group wall. Teacher and students can give feedback to the one another.

\section{METHOD}

The aims of the study are how Facebook used in English language class, how students' perspective of using Facebook in learning English and how Facebook maximize their skills. The design of the study is descriptive qualitative. Latief (2010) defines qualitative design as an inquiry process to comprehend people's behavior, through complete description about cultural and social setting where the custom occurs. The participant of the study was 12 students.

The researcher did the following steps: giving instruction, gathering data and describing the result of the use of Facebook in learning English.

First, researcher gave assignment to the students. The assignment is using Facebook as learning media. Second students have to give comment to other students. They have to submit it.

Second step is gathering data, the data is the students status and comment on Facebook that they have submitted And the last step is analyzing and describing the result. 


\section{FINDINGS AND DISCUSSION}

The findings of this study will be described as follows:

1. How Facebook used in English language class

All of the students of 2015 intake are active users of Facebook. But when researcher asked them what kind of language they always use to write status, most of them replied in Indonesian language. So that the researcher thought why did not use it to practice our English. The use of Facebook is no more difficult to be applied. Considering the third activity proposed by Hanafi et al (2013), sharing personal experience or story was the activity chosen by the researcher. In this case the researcher adapt this activity. At the first time the researcher gave the assignment to the students. The assignment was each student has to write status on Facebook on their own wall. The minimum status written is three sentences. The status can be any kinds of experiences, motivation quotes (should student's own words) or invitation.

After writing the status on Facebook, they have to read their friends' status and give comment. The comment at least three sentences too. And each student has to write three comments to other students' status.

The following are the instruction of using Facebook in learning English.

1. Write status at least three sentences.

2. Read your friends status.

3. Give comment to your friend's status
4. The comment given should at least three sentences.

5. Each student has to give comment to three friends' status.

6. Screen-shot and submit.

7. It must be submitted three days after the instruction given.

After the instruction given students have to do screen-shot and submit via whats App (WA). The instruction is being obeyed by all participants. They submit the screen-shot on time and they are really enthusiastic.

2. How students' perspective of using Facebook in learning English

after giving that kind of assignment, the researcher gave some questionnaire, here are the responds of the students.

Question no.1 the researcher asked whether they are Facebook user or not, the answer of this question is all participants are Facebook users. While the second question given 'I like to update FB status' the respond is $66 \%$ said disagree, Neutral and Agree the same amount of respond they are $17 \%$ each. It means although they are Facebook users, they dislike to write status on their Facebook Although they rarely write on their Facebook, it is rather contrast when the answer of question number 5. with the statement 'I like to write English status in Bahasa' $50 \%$ of the participants said that they like to post their status in Indonesian Language. $17 \%$ of the participant said that she always write status in Indonesian language. While $17 \%$ said neutral and the rest said disagree. The researcher assumes 
that some of them also sometimes write their status not only in Indonesian language but also another language such as English or Javanese.

When they were asked whether they like to give comment to their friend's status or not, like in the third question, the respond is $16.6 \%$ said agree, $16.6 \%$ said Neutral and $16.6 \%$ said disagree. From the respond, the researcher assumes that the frequency of commenting friends' status is depend on their mood. If they want to give comment they will do it and if they do not want to do it, they never do it.

Reading interest given in the eighth question 'I like to read English Facebook. neutral is the highest respond number from the participant they are $66 \%$ from the total amount of the participant. $17 \%$ said strongly agree and $17 \%$ said agree. It can be assumed that almost all respondents do not like to read other status especially written in English.

When they were asked whether Facebook contributes to their English learning $66 \%$ said agree and 34\% said neutral. The expectation of using Facebook as learning media appear in the respond of the tenth question, that is 'I will propose FB as learning media to all of my friends'. the respond is $83 \%$ of the total amount of the participant agree with this statement while only $17 \%$ said neutral. It means that they has been realized that Facebook can be an alternative way to learn English.

Statement No.12 asked the participant about the usage of Facebook in the classroom. Do they use Facebook to communicate with friends in a class? The answer is they rarely use Facebook to communicate with classmate. It can be known from their responds. They said neutral $66 \%$ and said disagree $34 \%$. it means that there is no one from the participant use Facebook as tool of communication to their classmate.

The last statement is FB motivates me in learning English and the respond of this statement is only $17 \%$ of total amount of the participants said agree, $66 \%$ said neutral and the rest said disagree.

Detail information about the respond of the questionnaire can be seen on the table 1 . 
Table 1: participant responses

\begin{tabular}{|c|c|c|c|c|c|c|c|}
\hline \multirow[b]{2}{*}{ No } & \multirow[t]{2}{*}{ statement } & \multicolumn{4}{|c|}{ percentage } & \multicolumn{2}{|c|}{ Total $(\%)$} \\
\hline & & SA & A & $\mathrm{N}$ & DA & SDA & \\
\hline 1 & I am Facebook user & 100 & 0 & 0 & 0 & 0 & 100 \\
\hline 2 & I like to update FB status & 0 & 17 & 17 & 66 & 0 & 100 \\
\hline 3 & $\begin{array}{l}\text { I always give comment to my } \\
\text { friends status }\end{array}$ & 0 & 0 & 50 & 33 & 17 & 100 \\
\hline 4 & $\begin{array}{l}\text { I like to write FB status in } \\
\text { English }\end{array}$ & 0 & 33.3 & 33.3 & 33.3 & 0 & 100 \\
\hline 5 & $\begin{array}{l}\text { I like to write English status in } \\
\text { Bahasa }\end{array}$ & 16.6 & 50 & 16.6 & 16.6 & 0 & 100 \\
\hline 6 & $\begin{array}{l}\text { I always write everything on } \\
\text { FB }\end{array}$ & 0 & 0 & 0 & 0 & 100 & 100 \\
\hline 7 & $\begin{array}{l}\text { I really like if there is } \\
\text { assignment given via } \mathrm{FB}\end{array}$ & 0 & 66 & 34 & 0 & 0 & 100 \\
\hline 8 & I like to read English Facebook & 17 & 17 & 66 & 0 & 0 & 100 \\
\hline 9 & $\begin{array}{l}\text { I will use FB as my learning } \\
\text { media }\end{array}$ & 0 & 66 & 34 & 0 & 0 & 100 \\
\hline 10 & $\begin{array}{l}\text { I will propose FB as learning } \\
\text { media to all of my friends }\end{array}$ & 0 & 83 & 17 & 0 & 0 & 100 \\
\hline 11 & $\begin{array}{l}\text { FB contribute to me in learning } \\
\text { English }\end{array}$ & 0 & 34 & 66 & 0 & 0 & 100 \\
\hline 12 & $\begin{array}{l}\text { Using FB is useful to } \\
\text { communicate with friends in a } \\
\text { class }\end{array}$ & 0 & 0 & 66 & 34 & 0 & 100 \\
\hline 13 & $\begin{array}{l}\text { FB motivates me in learning } \\
\text { English }\end{array}$ & 0 & 17 & 66 & 17 & 0 & 100 \\
\hline
\end{tabular}

3. How Facebook maximize Learning English

Considering the result of the questionnaire, the researcher try to look forward to the result of the assignment given. The assignment have been submitted and the researcher has analyzed the assignment given.

Firstly, participant status

From the status of the participants, most of the status that they had written are beautiful inspiration and motivation words. There are 6 status of giving motivation and inspiration, 2 status of their lovely pet, 2 status of invitation of celebrating new year, 1 status for sharing experience and 1 status for saying happy new year.

Secondly how does Facebook status maximize students in learning English.

The answer is when one writes a status it will make other students give comment. The researcher believes that they are not worry of making mistake such as when they are in class and talk to other with teacher/lecturer in it.

The following is the example of giving motivation and inspiration 


\section{.}

$22 \%$

facebook

Sunting · Hapus

Aisyah Setyaningrum bersama Dhea Rizky Tamara dan 10 lainnya.

Life will always have a different plan for you. If you don't give up, you will eventually get to your destination. But towards the end of your life, you may look back and realize that it was never really about the destination, it was the journey that counted.

$31 \mathrm{mnt} \cdot$ Privasi: Publik

Tambahkan Foto · Lainnya
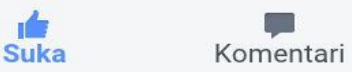

Bagikan

Anda, Windakhurniasari, dan 6 lainnya

Sinta Novia

we did not have the same fate but we could go on holiday together

Suka - Balas - Hapus - Laporkan - 26 menit yang lalu

Gloria Maganda

What's plan in your life?

Suka - Balas - Hapus - Laporkan - 23 menit yang lalu

Mahela Usfia Kurniasari

"life will always have different plan for you".

That's really great words. We never know what will happen tomorrow until the end of our llife.

Batal Suka - 1 1 Balas · Hapus - Laporkan - 10 menit yang

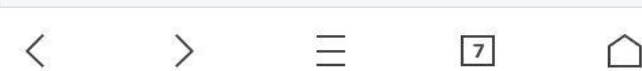

She wrote 'life will always have different plan for you. If you don not give up. You will eventually get your destination. But towards the end of your life, you may look back and realize that it was never really about the destination. It was the journey that counted'. This motivation makes other students give comment such as M's comment of the quotation "life will always have different plan for you" that's really great word. We never know what will happen tomorrow until the end of our life.

Unbelievable that who share about their lovely pet got so many comments. Take an example of Glo's Status

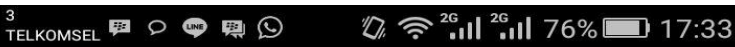

35. Gloria Maganda menambahkan 2 foto baru. $6 \mathrm{jam} \cdot 28$

I'm so sad because yesterday my dog's gaving birth. But she's still so young and not ready to give birth. Now three puppies died, only two left. Until now, she's still on her pregnancy period. Perhaps her puppies inside her womb is going to die as well... [a
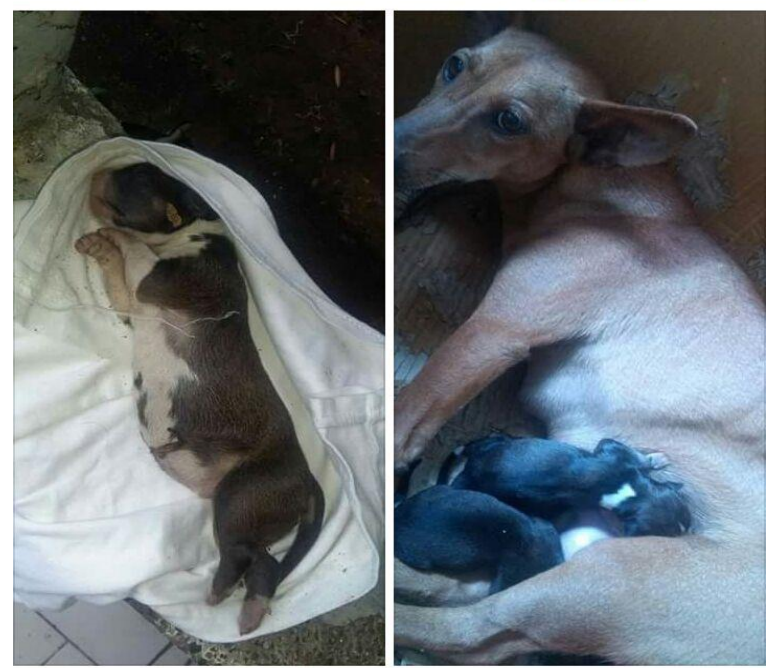

(1):- Julian Bintoro dan 12 lainnya 65 Komentar

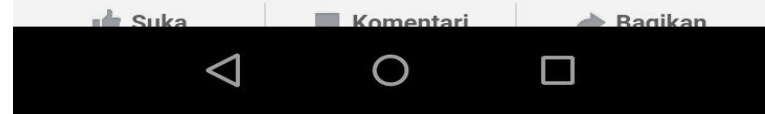

Her sharing of her dog that had newborn baby had 65 comments afterwords. Many of them gave their sorry for died puppy, some of them said congratulation of the birth. All the comment run smoothly as they never think that they make any mistake in using English. This is the most wanted in learning English. Never shy to say anything in English so that you can speak properly.

Another status was about invitation to celebrate new year event 


\section{7:35PM it mll Axis $\mathrm{H}$.ul INDOSATOOREDOO $\square 56 \%$ \\ $\leftarrow$ Kiriman \\ friendship. Will you come to my house to celebrate the end of this year guys? Maybe we can celebrate the end of this semester too before we do final examination.;(;):(5) (:)

$$
\text { 는 Suka } \quad \Rightarrow \text { Komentar } \rightarrow \text { Bagikan }
$$ \\ Anda, Aditya Galih Agustin, dan 8 lain \\ Dhea Rizky Tamara \\ I'm sorry adit. I cant go to your house for new year celebrate because you know that i cant ride motorcycle and no one pick me up to your home \\ 2 jam yang lalu ' Suka · Balas \\ Ilmatul Khoiro \\ Maybe you can go to Aditya Galih Agustin house by public transportation, than you can stay at my home for one night $\$$ \\ 2 jam yang lalu · Suka · Balas \\ Dhea Rizky Tamara \\ thats good idea ilma, but my mom wont allow me $\theta$ \\ O) \\ Tulis komentar...}

The first sentence of this status actually is not true. She said 'friendship'. It should be replaced by 'Hi Friends'. It indicates that they are really free to express their feelings. Although some expressions are written incorrect term, they still learn to write in English and this will make them confident in speaking and writing English. The time the researcher asked them to write status in English was on the last month of 2016, Desember, so that there are two students wrote invitation of celebrating new year one student asked their friend to her house and one student asked his friends to paralayang, tourism object which is located in Batu. Respond of this invitation is various. Some of them respond with many kind of food that they would have to bring, some of them refuse the invitation because of some reason such as one of them said " I am sorry Adit, you know that I cannot ride motorcycle. They can express everything there on their Facebook.

Furthermore students also express what they have done or what they were doing at that time they wrote status . it can be seen from one of the students' status. She wrote the status when she went to the movie. She expressed her feeling after watching that comedy film by saying " that is make my mind fresh". in this case the writer really enjoy the movie so she felt fresh after watching it. Not only expressed her feeling she also commented on the actor by saying 'Bigthumbs up for Raditya, Bayu Skak and friends". he expressing of feeling good can be written on Facebook too. Perhaps she never imagine to express her feeling using English.

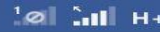 [C] $15: 56$}

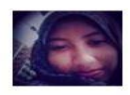

Mahela Usfia Kurniasari

menambahkan 4 foto baru.

sekitar seiam lalu (a)

It is Hangout time!!!!! That is make my mind fresh. Big thumbs up for raditya, bayu skak and friends.

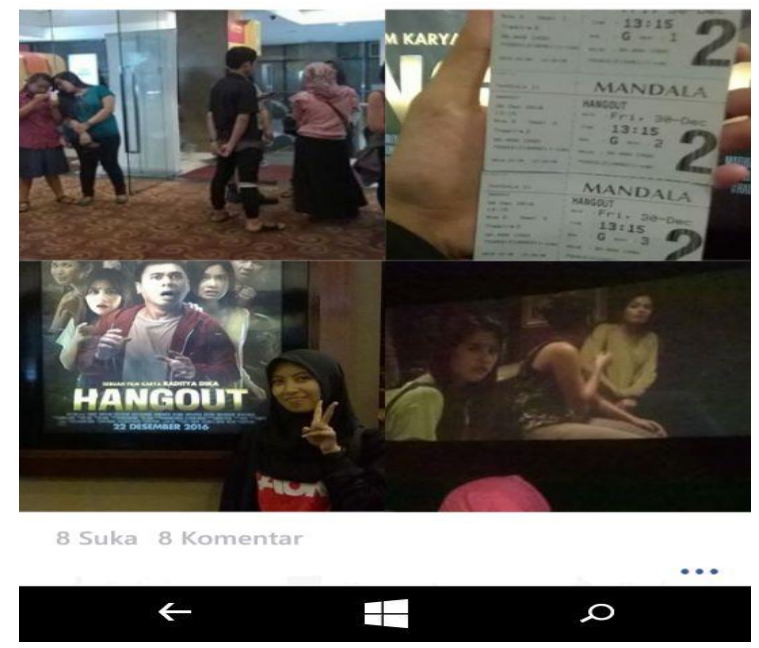


Although in the questionnaire less of them said that they like to write status or comment using English language, here the researcher found that they are really enjoy doing this assignment. Many comments come from their friends also using English.

Brown (2007:73) said that successful language learners generally believe in themselves and in their capacity to accomplish communicative tasks, and therefore willing risk takers in their attempts to produce and to interpret language that is a bit beyond their absolute certainty. Their willingness to communicate results in the generation of both output (from the learner) and input (to the learner).

It is the time to start and maximize English learning through media that we have had for many years. We cannot abuse the technology in front of our eyes. Use it, take benefit from it.

\section{CONCLUSION}

From the findings and discussion, researcher can conclude that Facebook is nice media to learn English. There are many advantages that the students can do with Facebook. Sharing their experience, learning English writing and speaking in case how to give opinion and suggestion. Facebook can be alternative tool in learning English without nay worrying of making mistakes in grammatical error and other.

Remembering that this research is only conducted on 12 participants, the researcher expects that the future researchers who have willingness to do the same research would take broaden participant and different level of students.

Lecturer should be creative in giving the material and using media in learning English, so that learning English will run interesting, not monotone and enjoyable. 


\section{REFERENCES}

Brown, H Douglas. 2007. Teaching by principles: an interactive approach to language pedagogy third edition. USA: Pearson Education, inc

Hanafi, H. et all. (2015). Utilising Facebook to Enhance Students's learning Experience in the Digital Era: Promoses and Possibilities. International journal of Science and Research. (online)Vol.4 Issue2, February 2015 (http://www.ijsr.net, accessed on 07 January 2017)

Latief, M.A. 2010. Tanya Jawab Penelitian Pembelajaran Bahasa. Malang: UM press.

Mazman, S.G. \&Uslue, Y.K (2010). Modeling Educational Usage of Facebook. Computer and Education, vol.55 No.2, pp.444-453

Qodriane, L.U. (2013) The Use of Facebook Group Facility in Poetry Class. Teflin International Proceeding P. 664-667

Rokhayani, A. (2012) the Use of Facebook As An Alternative Media in Learning English. Teflin International Proceeding P. 39-42

Wang, C. \& Chen C. (2013). Effects of Facebook Tutoring on Learning English as A Second Language. AIDS International Conference e-Learning 2013 pp. 135-142 